\title{
Experimental Investigation of Fuel Quality and Contaminant Materials from Liquefied Petroleum Fuel
}

\author{
Jae-Kon Kim*, Kyong-Il Min, Eui Soon Yim \\ Research Institute of Petroleum Technology, Korea Petroleum Quality Distribution \& Authority (K-Petro), \\ Cheongju-City, Chungcheongbuk-do, Republic of Korea \\ Email: ${ }^{*}$ jkkim@kpetro.or.kr
}

Received 16 July 2014; revised 17 August 2014; accepted 26 August 2014

Copyright (C) 2014 by authors and Scientific Research Publishing Inc.

This work is licensed under the Creative Commons Attribution International License (CC BY). http://creativecommons.org/licenses/by/4.0/

c) (i) Open Access

\begin{abstract}
In this study, the quality characteristics and residue analysis in circulated LPG fuel were investigated experimentally in Korea. Quality characteristics in circulated LPG fuel were examined with samples of LPG in the supply chain (refinery, petrochemical, and imported LPG), transport, gas stations, and vehicles. The experimental results showed that quality of all circulated LPG was well within the quality standard guideline of LPG in Korea. Especially, it has shown average $13 \mathrm{wt}$ ppm in sulfur content over the full circulated LPG. The residue samples in LPG fuel were extracted on 2 L scale with acetonitrile and analyzed by gas chromatography-mass spectrometry (GC-MS). The components of residues in LPG were composed of 62 organic chemicals with $C_{3} \sim C_{28}$ and the main ingredients of residue were plasticizers ((di-octyl phalate (DOP), di-octyl adiphate (DOA) etc.), lubricant oil and amine compounds. It was also showed that mass of residue in vehicles was increasing compared with supply (refinery, petrochemical, and imported LPG). It was presumed that this residue had been originated from automotive LPG fuel, vehicle components, and lubricant oil in infrastructure.
\end{abstract}

\section{Keywords}

LPG (Liquefied Petroleum Gas), Residue Oil, Plasticizer

\section{Introduction}

Liquefied petroleum gas (LPG) is another alternative fuel with a high octane number. Alternative automotive fu-

${ }^{*}$ Corresponding author. 
els with lower carbon content than gasoline and diesel fuel, such as LPG with a mixture of propane $\left(\mathrm{C}_{3} \mathrm{H}_{8}\right)$ and butane $\left(\mathrm{C}_{4} \mathrm{H}_{10}\right)$ [1], have been widely investigated for reducing exhaust emissions [2]-[8]. Because LPG fuel primarily consists of simple hydrocarbon compounds, and the emissions from LPG-driven vehicles contain lower levels of hydrocarbon compounds, nitrogen oxides, sulfur oxides, air toxins and particulates. LPG is a byproduct generated in petroleum refineries, which is widely used as fuels in residential, industrial and vehicle application. The composition of LPG depends on its end use and varies greatly according to season, country, property of the crude oil/gas supply used and refining process.

Usually, LPG contains certain amount of residues such as hydrocarbons with higher vaporization points falling in the range of lubricants oils $\left(>\mathrm{C}_{18}\right)$ [9]. The residues amount in LPG is an important quality control item and it can accumulate in pipes, vaporizers, instruments and regulators, resulting in mal-flow and misreading. Recently, on specific applications, residue concentrations in LPG have to meet industrial codes. For instance, the Australian LPG Association requires the residues concentration below 20 mass ppm for vehicle use [10].

As a low carbon and low polluting fossil fuel, it is recognized by governments around the world for the contribution, and it can make towards improved indoor and outdoor air quality and reduced greenhouse gas emission [11]. Especially, it is recognized as a clean fuel in Korea and a part of the Korean Government energy supply plan. For this reason, while demand for propane is stagnant, demand for butane has increased since 2000. LPG consumption is 8.63 million tonnes in 2011 and nearly 49\% of the LPG consumption is for LPG vehicles. In 2011, 2.43 millions of LPG vehicles were registered to be used throughout the nation, with more than 1948 of LPG gas stations in operation in Korea [12].

The technology for LPG vehicles and LPG fuel in Korea was recognized as a global top. Nevertheless, it recently reported complaints about problems being experienced with the performance of vehicles operating on LPG in Korea. Recently, the problem was being attributed by LPG installer and component suppliers to contaminants in the LPG, an oily substance which was being deposited in vaporizer and injector in vehicles as shown in Figure 1 [13].

Of particular significance was the concern being expressed by a major LPG companies. Under these circumstances, this study was carried out to investigate characteristics of residues in circulated LPG fuel to determine the origin of the offending oily material deposited in the vehicle components, such as vehicle vaporizer and injector in LPG vehicle fuel system.

In this study, the quality characteristics and residue analysis in circulated LPG fuel was investigated experimentally. Quality characteristics in circulated LPG fuel were examined with samples of distribution supply step (refinery, petrochemical, and imported LPG), transport step, gas station step, and vehicle step) in Korea. The residue samples in circulated LPG were extracted with acetonitrile after evaporated on $2 \mathrm{~L}$ scale and it was analyzed to determine the origin of residue contaminations by gas chromatography-mass spectrometry (GC-MS) for component analysis.

\section{Experimental}

\subsection{Sample Preparation}

The samples of LPG used in the work were obtained from the supply chain as the supply step (refinery, import, petrochemical), transport step, gas station step and vehicle step as shown in Figure 2. The LPG supply system

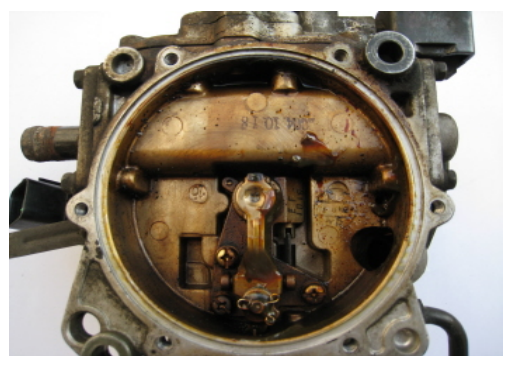

(a)

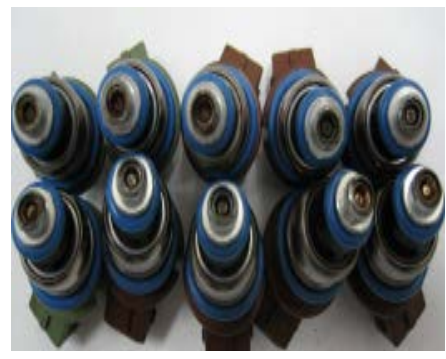

(b)

Figure 1. The contamination in vaporizer and injector from LPG vehicles. (a) Vaporizer contamination; (b) Injector contamination. 

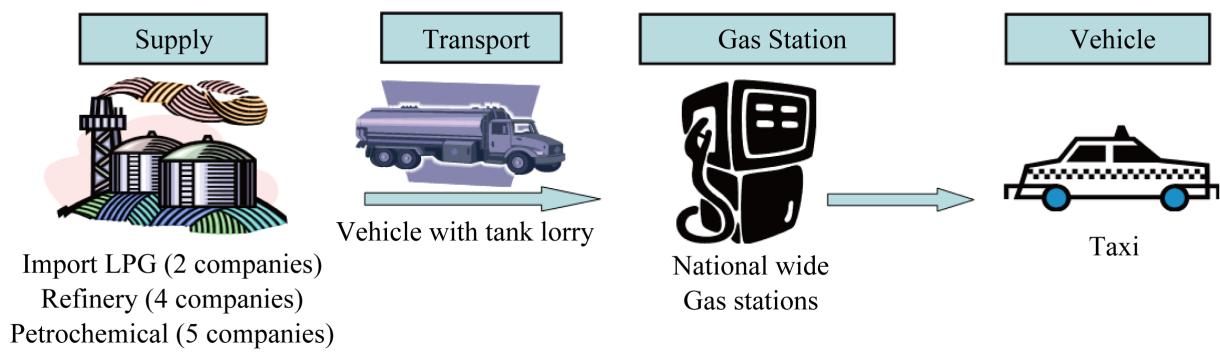

Figure 2. The scheme of experimental sampling of LPG fuel in distribution.

commences at the point where LPG is produced and ends at the point where LPG is dispensed into a vehicle at a gas station. The quality characteristics were tested with 142 samples of LPG in the supply chain for quality specification. The residue component was analyzed with LPG of $2 \mathrm{~L}$ to obtain enough residue concentration and in this method sample quantity was increased by 20 times compared with $100 \mathrm{~mL}$ as current test method in ASTM D2158-02. The 142 LPG samples for residue analysis were poured in the separatory funnel with $2 \mathrm{~L}$ scale and these were evaporated in hood at room temperature for 6 hours. Finally, the residue in separatory funnel was extracted with acetonitrile sometimes and dried to obtain brown oily residue at room temperature as shown in Figure 3.

\subsection{Test Method for LPG Quality}

The detailed specification of LPG fuel in this study was listed in Table 1 [14]. The quality of LPG fuel was determined by their physical and fuel properties including composition, sulfur content, vapor pressure, density, residues, and copper corrosion.

\subsubsection{LPG Composition}

The C3 and C4 composition including olefins in LPG samples were determined by following the KS M ISO 7941, using gas chromatography (GC) (Agilent Technologies 7890A, Palo Alto, USA) equipped with a flame ionization detector (FID) and a chromatography data management system. The fused silica capillary column (SP-2380 model, Supelco, Inc., USA) used in the GC analyzer was $30 \mathrm{~m}$ in length and $0.25 \mathrm{~mm}$ in inside diameter, with a film thickness of $0.2 \mu \mathrm{m}$.

\subsubsection{Sulfur Content and Residue Content}

For sulfur content, the test was measured by elemental analyzer system NSX-2100V (Mitsubishi Chemical Corporation, Japan) according to ASTM D 6667. The residue was measured by cone-shaped centrifuge tube (Koehler, USA) according to ASTM D 2158 on $100 \mathrm{~mL}$ scale.

\subsubsection{Vapor Pressure, Density and Copper Corrosion}

The vapor pressure was measured by a rapid equilibrium closed cup method (Lawler, USA) according to KS M ISO 4256. The density was measured at $15^{\circ} \mathrm{C}$ by digital density meter K-25990 (Koehler, USA) using KS M 2150. The copper corrosion was evaluated according to KS M 6151.

All experiments were carried out in triplicate, showing no statistically significant difference between measures. The arithmetic mean of the three determinations was taken as the final result. In addition, the uncertainties were calculated to confirm that each instrument meets the limits of accuracy as set by the specifications of the standard method.

\section{Test method for LPG residue analysis}

The condition of GC-MS is showed in Table 2. The GC-MS system consisted of an Agilent 7890A GC (Agilent Technologies, Shanghai, China), equipped with an Agilent 7683 auto injector (Agilent Technologies, Shanghai, China), coupled to an Agilent 5975C mass-selective detector (Agilent Technologies, Santa Clara, CA, USA). The GC was fitted with HP-5MS fused silica capillary column (5\% phenyl methyl siloxane as non-polar stationary phase, $30 \mathrm{~m} \times 0.25 \mathrm{~mm}$ i.d. and $0.25 \mu \mathrm{m}$ film thickness) from Agilent (J\&W Scientific, Folson, CA, USA). The oven temperature program was held at $40^{\circ} \mathrm{C}$ for $3 \mathrm{~min}$, ramped to $240^{\circ} \mathrm{C} / \mathrm{min}$ and held $240^{\circ} \mathrm{C}$ for 10 min. Injector and transfer line temperatures were $150^{\circ} \mathrm{C}$ and $280^{\circ} \mathrm{C}$, respectively. The flow rate of the carrier gas 


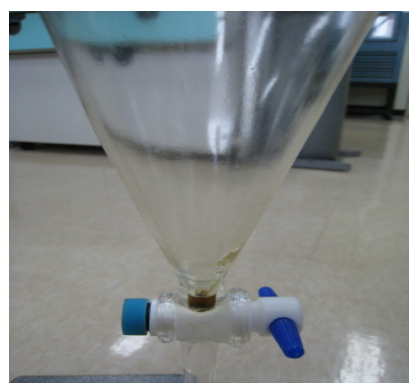

(a)

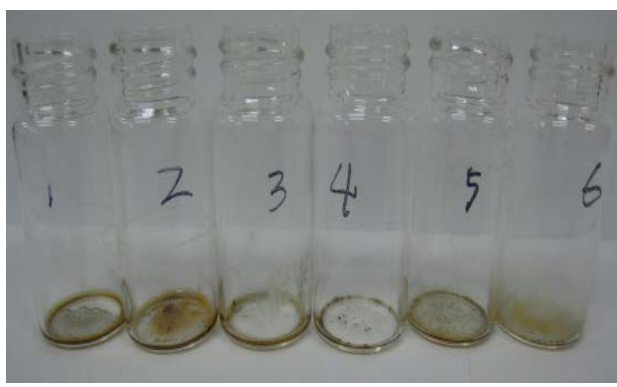

(b)

Figure 3. Extracted residue samples from LPG fuel for GC-MS analysis. (a) Residue in separatory funnel after evaporation; (b) Residue for GC-MS analysis.

Table 1. Test methods for quality specifications of automotive LPG fuel in this experimental.

\begin{tabular}{|c|c|c|c|c|}
\hline \multirow{2}{*}{\multicolumn{2}{|c|}{ Item }} & \multicolumn{2}{|c|}{ LPG standard } & \multirow{2}{*}{ Test method } \\
\hline & & Summer & Winter & \\
\hline \multirow{3}{*}{$\begin{array}{l}\text { Composition } \\
\text { (mol \%) }\end{array}$} & C3-Hydrocarbon & Max. 10 & $15 \sim 35$ & \\
\hline & C4-Hydrocarbon & Min. 85 & Min. 60 & KS M ISO 7941 \\
\hline & 1,3-Butadiene & \multicolumn{2}{|c|}{ Max. 0.5} & \\
\hline \multicolumn{2}{|c|}{ Sulfur content (mg/kg) } & \multicolumn{2}{|c|}{ Max. 40} & ASTM D 6667 \\
\hline \multicolumn{2}{|c|}{ Vapor pressure $\left(40^{\circ} \mathrm{C}, \mathrm{kPa}\right)$} & \multicolumn{2}{|c|}{ Max. 1.27} & KS M ISO 4256 \\
\hline \multicolumn{2}{|c|}{ Density $\left(15^{\circ} \mathrm{C}, \mathrm{kg} / \mathrm{m}^{3}\right)$} & \multicolumn{2}{|c|}{$500 \sim 620$} & KS M 2150 \\
\hline \multicolumn{2}{|c|}{ Residue (ml) } & \multicolumn{2}{|c|}{ Max. 0.05} & ASTM D 2158 \\
\hline \multicolumn{2}{|c|}{ Copper strip corrosion $\left(40^{\circ} \mathrm{C}, 1 \mathrm{~h}\right)$} & \multicolumn{2}{|c|}{ Min. 1} & KS M 6251 \\
\hline
\end{tabular}

Table 2. The conditions of GC-MS for LPG residue analysis.

\begin{tabular}{cc}
\hline Item & Condition \\
\hline GC-MS model & Agilent 7890A GC/EI/MSD (Agilent 5975 C) \\
Column & HP $5 \mathrm{MS}(5 \%$ Phenyl methyl siloxane $30 \mathrm{~m}, 250 \mu \mathrm{m})$ \\
Detector temperature & $280^{\circ} \mathrm{C}$ \\
Oven temperature condition & $40^{\circ} \mathrm{C}(5 \mathrm{~min}), 5^{\circ} \mathrm{C} / \mathrm{min}, 240^{\circ} \mathrm{C}(10 \mathrm{~min})$ \\
Carrier gas & $\mathrm{He} 9 \mathrm{kPa}, 1.5 \mathrm{~mL} / \mathrm{min}$ \\
Injection amount & $1.0 \mu \mathrm{l}$ \\
\hline
\end{tabular}

(He, 99.9995\%) was $1.5 \mathrm{~mL} / \mathrm{min}$. A split injection with a ratio of 1:25 was used. The electron impact ionization mass spectrometer was operated as follows: ionization voltage, $70 \mathrm{eV}$; ion source temperature, $200^{\circ} \mathrm{C}$; scan mode, 50.0 - 500.0 (mass range); scan speed, 1.31 scan/sec. The volatile organic compounds in LPG residue were identified by linear retention indices of a series of $C_{3}$ to $C_{30}$ by comparison of the mass spectra of each component with the Wiley (Wiley, New York, NY, USA) mass spectral library.

\section{Result and Discussion}

\subsection{Quality Characteristics of LPG in Distribution}

The quality characteristics of LPG fuel were tested with 142 samples in distribution. The experimental results showed that quality of all circulated LPG fuel was well within the limit by Korean specifications as shown in Table 3. Figure 4 shows a general GC chromatogram for composition analysis of butane in LPG fuel. The LPG 
Table 3. Average results for quality characteristics of automotive LPG samples in distribution.

\begin{tabular}{ccccccccc}
\hline \multirow{2}{*}{$\begin{array}{c}\text { Class } \\
\text { Item }\end{array}$} & \multicolumn{2}{c}{ LPG standard } \\
\cline { 2 - 8 } & Summer & Winter & Supply & Transport & Gas station & Vehicle & Average \\
\hline $\begin{array}{c}\text { Composition } \\
\text { (mol \%) }\end{array}$ & C3-Hydrocarbon & Max. 10 & $15 \sim 35$ & 1.1 & 10.3 & 14.1 & 6.8 & 8.7 \\
& C4-Hydrocarbon & Min.85 & Min. 60 & 98.4 & 91.2 & 85.3 & 92.1 & 91.1 \\
Sulfur content $(\mathrm{mg} / \mathrm{kg}$ ) & Max. 0.5 & 0.04 & - & - & 0.06 & 0.02 \\
Vapor pressure $\left(40^{\circ} \mathrm{C}, \mathrm{kPa}\right)$ & Max. 40 & 8.1 & 14.7 & 16.4 & 10.0 & 12.9 \\
Density $\left(15^{\circ} \mathrm{C}, \mathrm{kg} / \mathrm{m}^{3}\right)$ & Max. 1.27 & 0.45 & 0.58 & 0.57 & 0.42 & 0.52 \\
Residue $(\mathrm{ml})$ & $500 \sim 620$ & 578 & 570 & 569 & 574 & 572 \\
Copper strip corrosion $\left(40^{\circ} \mathrm{C}, 1 \mathrm{~h}\right)$ & Max. 0.05 & $0.05 \downarrow$ & Max. 0.05 & Max. 0.05 & Max. 0.05 & Max. 0.05 \\
\hline
\end{tabular}

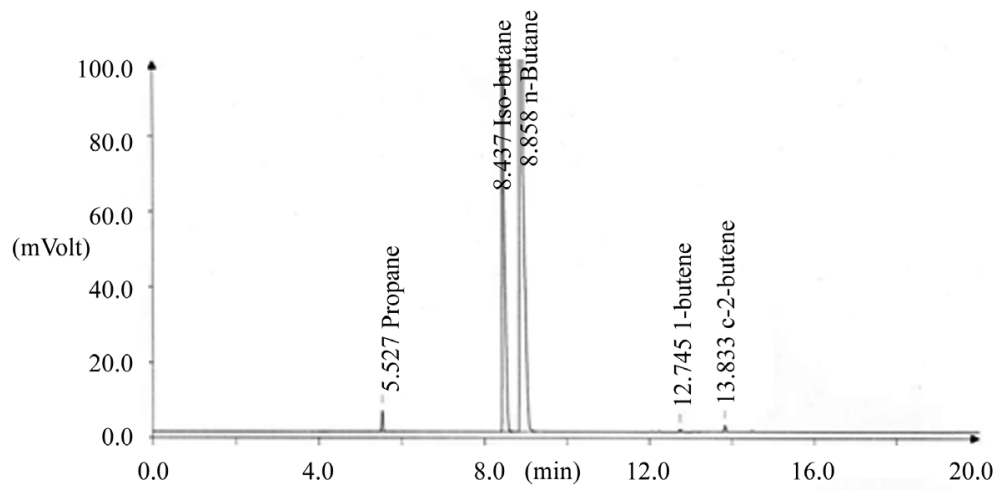

(a)

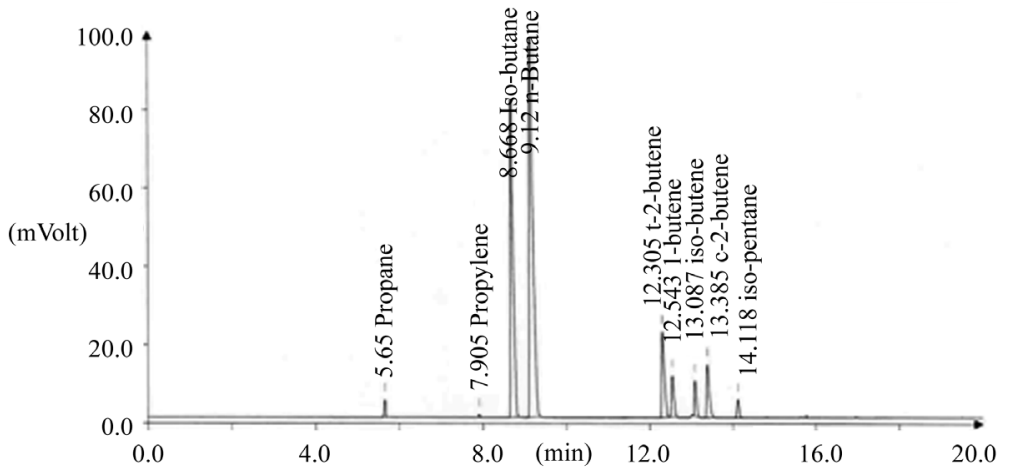

(b)

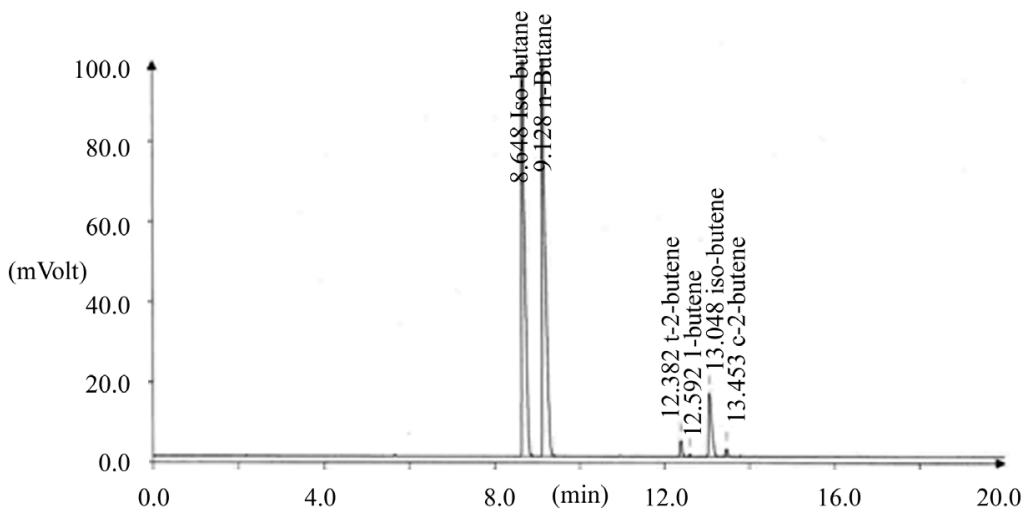

(c)

Figure 4. GC chromatogram for butane composition analysis of LPG fuel in supply step. (a) Importing butane; (b) Refinery butane; (c) Petrochemical butane. 
fuel composition was evaluated 8.7 mol\% for $\mathrm{C}_{3}$ hydrocarbon and $91.1 \mathrm{~mol} \%$ for $\mathrm{C}_{4}$ hydrocarbon by GC. Especially, the residue of LPG fuel was within the limit by Korean specifications on $100 \mathrm{~mL}$ scale as a current test method (ASTM D 2158) and was showed average $13 \mathrm{wt}$ ppm in sulfur content over the circulated LPG fuel.

Figure 5 shows a general GC chromatogram for olefin analysis of LPG in vehicle step. The olefin means a sum of unsaturated hydrocarbon such as t-2-butene, 1-butene, iso-butylene, c-2-butene, iso-butene, 1,3-butadiene in LPG composition. Kim et al reported that the olefin content with unsaturated hydrocarbons in LPG has an effect to extract plasticizers [15] [16]. The total olefin composition in distribution also was analyzed to be much as $3.2 \mathrm{~mol} \%$ average but it was a high level as $7.31 \mathrm{~mol} \%$ in vehicle step compared with other step as shown in Figure 6. It was statistically increased in the order of transport step < gas station step < vehicle step compared to supply step in distribution.

\subsection{Residues Analysis of LPG in Distribution}

The sources of the residues are the LPG processing equipment, compressors and containers. The amount of residue in LPG is an important quality control item, since it can accumulate in pipes, vaporizers, injectors, instruments and regulators, resulting in mal-flow and misreading. In Korea, the residues content in LPG is measured by ASTM D2158-02 test method. However, it can't give an enough residues concentration to analyze residue component because of a small amount of $100 \mathrm{~mL}$ in sampling. To investigate the characteristics of LPG residues for concentration, LPG fuel was evaporated with LPG of 2 L scale to get a more sample compared with contaminants causing problems experienced with the performance of vehicles operating. The residue analysis was

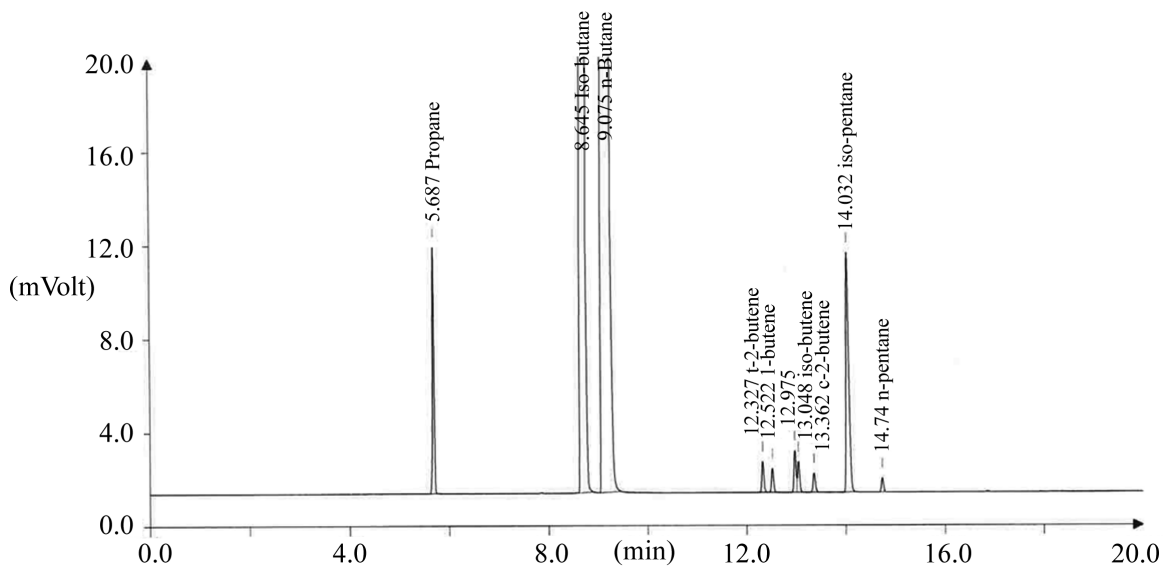

Figure 5. GC chromatogram for butane composition analysis of LPG fuel in vehicle step.

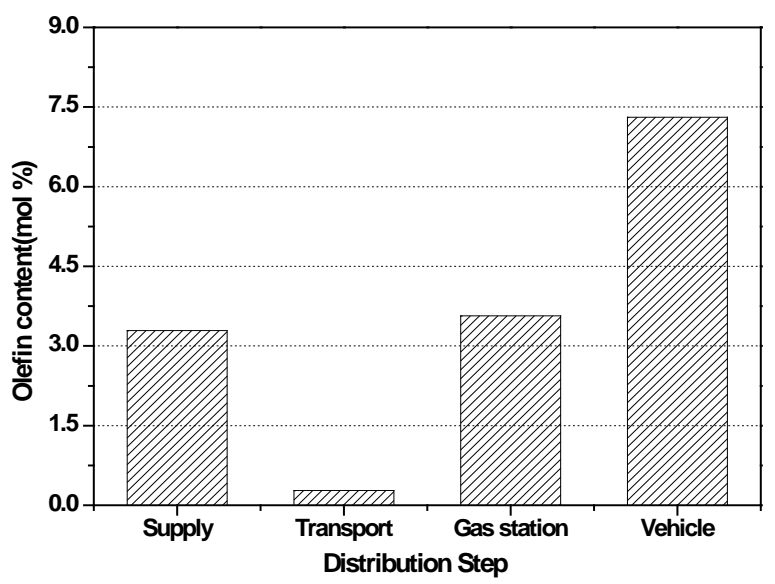

Figure 6. Total olefin content comparison of LPG (142 samples) in distribution (the olefin means a sum of unsaturated hydrocarbon in LPG composition). 
tested with 142 samples of LPG in distribution.

The amount of residues comparison of LPG on $2 \mathrm{~L}$ scale in distribution is shown in Figure 7 . The average total amount of residues in distribution is $19.58 \mathrm{mg} / 2 \mathrm{~L}$ and the amount of residue in vehicle step (45.63 mg/2L) is higher than supply step $(16.91 \mathrm{mg} / 2 \mathrm{~L})$. It showed that the amount of residue is increasing due to contamination on supply in distribution. Especially, Figure 8 indicated that the residue content of imported LPG was lower than refinery LPG, petrochemical LPG in supply step. The components of residues in LPG were detected 62 hydrocarbon chemicals with $C_{3} \sim \mathrm{C}_{28}$ same as plasticizers, alkane, alkenes and ester with high molecular formula in lubricant oil, amine components, sulfides and siloxane in Table 4. Especially, the main ingredients of residue were analyzed plasticizers same as di-n-octylphalate, di-octyladiphate, di(2-ethylhexyl)adipate, di-isooctylalipate, di(isodecyl)phthalate, di-heptyl phthalate by GC-MS in Table 5.

In general, plasticizers are used in the manufacture of plastics and rubbers to facilitate manufacture and make the products more flexible and softer to meet specific application requirements. Most plasticizers are liquid in their natural state and have an appearance similar to lubricant oil. The harmful plasticizer comprises mostly of either phthalates or adipates or a combination of these chemicals and they were found to have a detrimental effect on the rubber based components. Therefore, LPG residues with high molecular weight have an effect on fuel distribution system in Korea.

\section{Conclusions}

The objective of this research was to assess an investigation of characteristic of residues in circulated LPG fuel

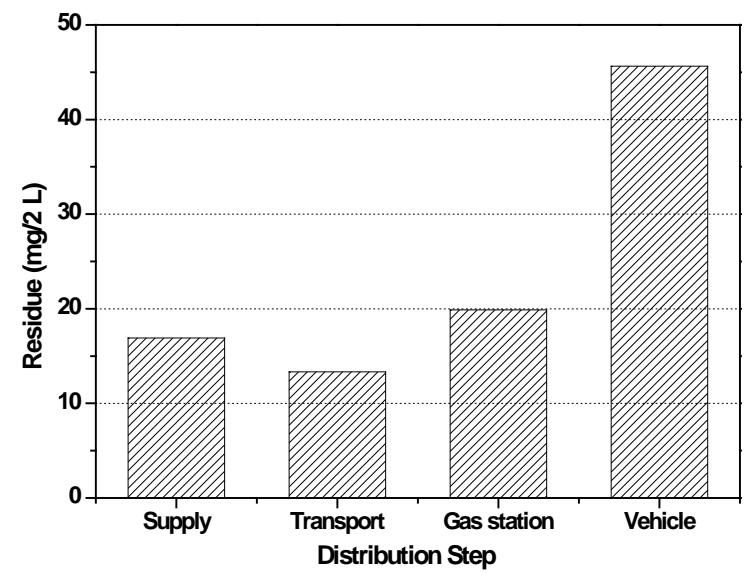

Figure 7. Total amount of residues (mg/2L) comparison of LPG (142 samples) in distribution.

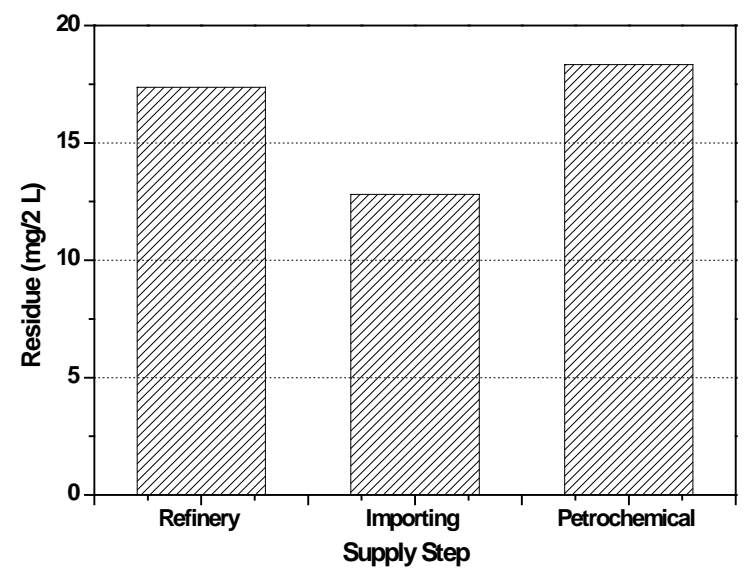

Figure 8. The amount of residues (mg/2L) comparison of LPG (142 samples) in supply step. 
Table 4. The residue components from automotive LPG fuel in distribution.

\begin{tabular}{|c|c|c|c|}
\hline Class & Component & Molecular formula & Detection step in distribution ${ }^{\mathrm{a}}$ \\
\hline \multirow{10}{*}{ Alkanes } & 2,2-dimethyl butane & $\mathrm{C}_{6} \mathrm{H}_{14}$ & G \\
\hline & Isodecane & $\mathrm{C}_{10} \mathrm{H}_{22}$ & G \\
\hline & Undecane & $\mathrm{C}_{11} \mathrm{H}_{24}$ & S \\
\hline & 2,2,6,6-tetramethylheptane & $\mathrm{C}_{11} \mathrm{H}_{24}$ & G \\
\hline & Dodecane & $\mathrm{C}_{12} \mathrm{H}_{26}$ & G \\
\hline & Tridecane & $\mathrm{C}_{13} \mathrm{H}_{28}$ & G \\
\hline & 2,6,7-trimethyl-decane & $\mathrm{C}_{13} \mathrm{H}_{28}$ & G \\
\hline & Hexadecane & $\mathrm{C}_{16} \mathrm{H}_{34}$ & G \\
\hline & Tetracosane & $\mathrm{C}_{24} \mathrm{H}_{50}$ & G \\
\hline & n-Hexacosane & $\mathrm{C}_{26} \mathrm{H}_{54}$ & G \\
\hline \multirow{11}{*}{ Amines } & n-Octacosane & $\mathrm{C}_{28} \mathrm{H}_{58}$ & $\mathrm{~S}$ \\
\hline & Ethamine & $\mathrm{C}_{2} \mathrm{H}_{7} \mathrm{~N}$ & $\mathrm{~S}$ \\
\hline & 1,3,4-Thiadiazol-2-amine & $\mathrm{C}_{2} \mathrm{H}_{3} \mathrm{~N}_{3} \mathrm{~S}$ & $\mathrm{~S}$ \\
\hline & 1,2-Ethanediamine & $\mathrm{C}_{2} \mathrm{H}_{8} \mathrm{~N}_{2}$ & G \\
\hline & Silanamine $\left(\mathrm{H}_{5} \mathrm{NSi}\right)$ & $\mathrm{H}_{5} \mathrm{NS}$ & G \\
\hline & N,N-dimethyl formamide & $\mathrm{C}_{3} \mathrm{H}_{7} \mathrm{NO}$ & G \\
\hline & Methyldiethanol amine (MDEA) & $\mathrm{C}_{5} \mathrm{H}_{13} \mathrm{NO}_{2}$ & G \\
\hline & 2,4,6-Trimehtyl-5H-1,3,5-dithiazin & $\mathrm{C}_{6} \mathrm{H}_{13} \mathrm{NS}_{2}$ & $\mathrm{~S}$ \\
\hline & 2-heptanamine & $\mathrm{C}_{7} \mathrm{H}_{17} \mathrm{~N}$ & $\mathrm{~S}$ \\
\hline & Diphenylamine & $\mathrm{C}_{12} \mathrm{H}_{11} \mathrm{~N}$ & $\mathrm{~T}$ \\
\hline & Octyl-diphenylamine & $\mathrm{C}_{20} \mathrm{H}_{27} \mathrm{~N}$ & $\mathrm{~T}$ \\
\hline \multirow{2}{*}{ Alkens } & 2,4,6-dodecatriene & $\mathrm{C}_{12} \mathrm{H}_{20}$ & $\mathrm{~S}$ \\
\hline & Dimethyl-formyl thiacyclohexene & $\mathrm{C}_{8} \mathrm{H}_{13} \mathrm{SO}$ & G \\
\hline \multirow{3}{*}{ Siloxane } & Ttrisiloxane & $\mathrm{H}_{8} \mathrm{O}_{2} \mathrm{Si}_{3}$ & $\mathrm{~S}$ \\
\hline & Pentasiloxane & $\mathrm{H}_{12} \mathrm{O}_{4} \mathrm{Si}_{5}$ & G \\
\hline & Cyclohexasiloxane & $\mathrm{H}_{12} \mathrm{O}_{6} \mathrm{Si}_{6}$ & S, G \\
\hline \multirow{5}{*}{ Sulfides } & Diethyldisulfide & $\mathrm{C}_{4} \mathrm{H}_{10} \mathrm{~S}_{2}$ & $\mathrm{~T}$ \\
\hline & Methyl tert-butyl disulfide & $\mathrm{C}_{5} \mathrm{H}_{12} \mathrm{~S}_{2}$ & $\mathrm{~T}$ \\
\hline & Bis(1,1-dimethylethyl)disulfide & $\mathrm{C}_{8} \mathrm{H}_{18} \mathrm{~S}_{2}$ & $\mathrm{~T}$ \\
\hline & Dibutyldisulfide & $\mathrm{C}_{8} \mathrm{H}_{18} \mathrm{~S}_{2}$ & $\mathrm{~S}$ \\
\hline & Di-n-octyl disulfide & $\mathrm{C}_{16} \mathrm{H}_{34} \mathrm{~S}_{2}$ & $\mathrm{~S}$ \\
\hline \multirow{4}{*}{ Esters } & Methyl cis-3-chloropropenate & $\mathrm{C}_{4} \mathrm{H}_{5} \mathrm{ClO}_{2}$ & G \\
\hline & Hexadecanoic acid methyl ester & $\mathrm{C}_{17} \mathrm{H}_{34} \mathrm{O}_{2}$ & G \\
\hline & Hexadecanoic acid methyl ester & $\mathrm{C}_{19} \mathrm{H}_{36} \mathrm{O}_{2}$ & G \\
\hline & Hexanedioic acid dioctyl ester & $\mathrm{C}_{22} \mathrm{H}_{42} \mathrm{O}_{4}$ & S \\
\hline
\end{tabular}

${ }^{\mathrm{a}} \mathrm{S}$ : supply step, T: transport step, G: gas station step, V: vehicle step. 
Table 5. The main ingredients of residues contaminations from automotive LPG fuel in distribution.

\begin{tabular}{ccc}
\hline Component & Molecular formula & Detection step in distribution $^{{ }^{a}}$ \\
\hline Di(2-ethylhexyl)adipate & $\mathrm{C}_{22} \mathrm{H}_{40} \mathrm{O}_{4}$ & $\mathrm{~S}, \mathrm{~T}, \mathrm{G}, \mathrm{V}$ \\
Di-isooctylalipate & $\mathrm{C}_{22} \mathrm{H}_{42} \mathrm{O}_{4}$ & $\mathrm{~S}, \mathrm{~V}$ \\
Di(isodecyl)phthalate & $\mathrm{C}_{28} \mathrm{H}_{44} \mathrm{O}_{4}$ & $\mathrm{G}$ \\
Di-heptyl phthalate & $\mathrm{C}_{22} \mathrm{H}_{34} \mathrm{O}_{4}$ & $\mathrm{G}$ \\
Bis(n-octyl)phthalate & $\mathrm{C}_{24} \mathrm{H}_{36} \mathrm{O}_{4}$ & $\mathrm{G}, \mathrm{T}$ \\
Di(2-ethylhexyl)phthalate & $\mathrm{C}_{24} \mathrm{H}_{38} \mathrm{O}_{4}$ & $\mathrm{~S}, \mathrm{~T}, \mathrm{G}$ \\
Di-nonyl phthalate & $\mathrm{C}_{26} \mathrm{H}_{42} \mathrm{O}_{4}$ & $\mathrm{G}$ \\
Di(7-methyloctyl)phthalate & $\mathrm{C}_{26} \mathrm{H}_{40} \mathrm{O}_{4}$ & $\mathrm{G}$ \\
\hline
\end{tabular}

${ }^{\text {a} S: ~ S u p p l y ~ s t e p, ~ T: ~ T r a n s p o r t ~ s t e p, ~ G: ~ G a s ~ s t a t i o n ~ s t e p, ~ V: ~ V e h i c l e ~ s t e p . ~}$

to determine the origin of the offending oily material which was being deposited in the vehicle components such as vehicle vaporizer and injector in vehicle fuel system. Recently, the problem was being attributed by LPG installer and component suppliers to contaminants in the LPG an oily substance which deposited in vaporizer and injector in vehicle.

The experimental results showed that quality of all circulated LPG was well within quality standard guideline of LPG in Korea. Especially, it showed average $13 \mathrm{wt}$ ppm in sulfur content over the full circulated LPG. The components of residues in LPG was detected 62 organic chemicals with $\mathrm{C}_{3} \sim \mathrm{C}_{28}$ hydrocarbon compounds and the main ingredients of residue were plasticizers ((di-octylphalate (DOP), di-octyladiphate (DOA) etc.), lubricant oil and amine components. Finally, it was presumed that this residue had been originated from automotive LPG fuel, vehicle components and lubricant oil in infrastructure. LPG residue with high molecular weight has an effect on fuel distribution system in Korea.

\section{Acknowledgements}

This research was supported by Korea LPG Association (KLPGA) and we sincerely appreciate the support of KLPGA.

\section{References}

[1] Keith, O.K. (1995) Automotive Fuels Reference Book. Society of Automotive Engineers, USA.

[2] Boretti, A. (2009) Development of a Direct Injection High Efficiency Liquid Phase LPG Spark Ignition Engine. SAE Paper, No. 2009-01-1881.

[3] Chiriac, R., Raud, R., Niculescu, D. and Apostolescu, N. (2003) Development of a LPG Fueled Engine for Heavy Duty Vhicles. SAE Paper, No. 2003-01-3261.

[4] Goto, S., Lee, D., Shakal, K., Harayama, N. and Ueno, H. (1999) Performance and Emission of an LPG Lean-Burn Engine for Heavy Duty Vehicles. SAE Paper, No. 1999-01-1513.

[5] Kim, C., Lee, D., Oh, S., Kang, K., Chol, H. and Min, K. (2002) Enhancing Performance and Combustion of an LPG MPI Engine for Heavy Duty Vehicles. SAE Paper, No. 2002-01-0449.

[6] Lee, J.W., Do, H.S., Kweon, S.I., Park, K.K. and Hong, J.H. (2010) Effect of Various LPG Supply Systems on Exhaust Particle. International Journal of Automotive Technology, 6, 119-124.

[7] Myung, C.L., Lee, H., Choi, K., Lee, Y.J. and Park, S. (2009) Effects of Gasoline, Diesel, LPG and Low-Carbon Fuels and Various Certification Modes on Nanoparticle Emission Characteristics in Light-Duty Vehicles. International Journal of Automotive Technology, 10, 537-544. http://dx.doi.org/10.1007/s12239-009-0062-9

[8] Park, K. and Han, S. (2004) The Ignition Characteristics for the Direct Liquid Injection Combustion in LPG Engine. FISITA Paper, No. 20042357.

[9] Zhuang, Q., Yodatani, J. and Kato, M. (2005) Accurate Measurement Method for the Residues in Liquefied Petroleum Gas (LPG). Fuel, 84, 443-446. http://dx.doi.org/10.1016/j.fuel.2004.09.005

[10] Government of Western Australia (2008) Investigation of the Cause and Consequences of Contaminants in Autogas Vehicle Systems. 2008 Report. 
[11] Goto, S., Wakasa, R. and Lee, D. (2001) Research Trends of LPG-Fueled Engine System. Journal of the Society of Automotive Engineers of Japan, 55, 30-37.

[12] Korea LPG Association (2011) Statistical Review of Global LP Gas. 2011-Report.

[13] Korea LPG Association (2009) Study of the Origin of Unknown Materials in LPG Distribution. 2009 Report.

[14] Korea Petroleum Quality \& Distribution Authority (2014) Fuel Quality Standards for Liquefied Petroleum Gas in Korea. http://www.kpetro.or.kr/sub.jsp?MenuID=m2as402

[15] Kim, Y.U. (2002) The Component and Compositional Analysis of Trace Materials in LPG. Journal of the Korean Chemical Society, 46, 317-322. http://dx.doi.org/10.5012/jkcs.2002.46.4.317

[16] Kim Y.U. (2004) Extraction Property of Plasticizer in LPG High Pressure Rubber Hose. Journal of the Korean Chemical Society, 48, 156-160. http://dx.doi.org/10.5012/jkcs.2004.48.2.156 
Scientific Research Publishing (SCIRP) is one of the largest Open Access journal publishers. It is currently publishing more than 200 open access, online, peer-reviewed journals covering a wide range of academic disciplines. SCIRP serves the worldwide academic communities and contributes to the progress and application of science with its publication.

Other selected journals from SCIRP are listed as below. Submit your manuscript to us via either submit@scirp.org or Online Submission Portal.
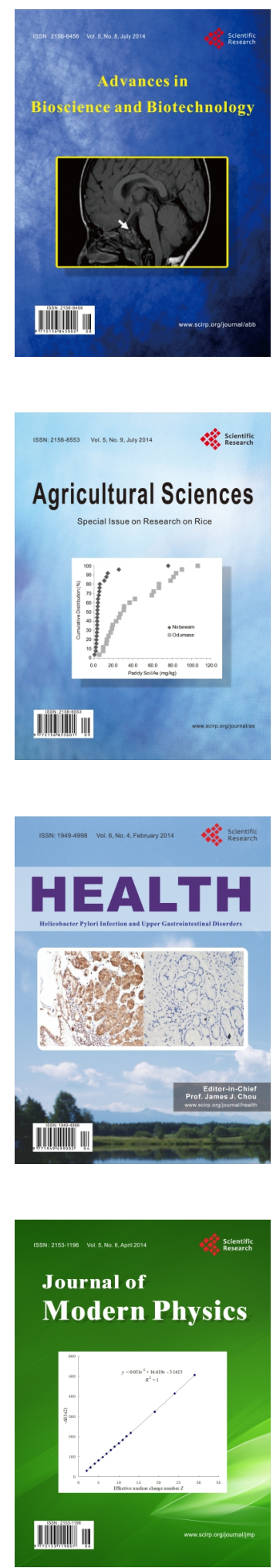
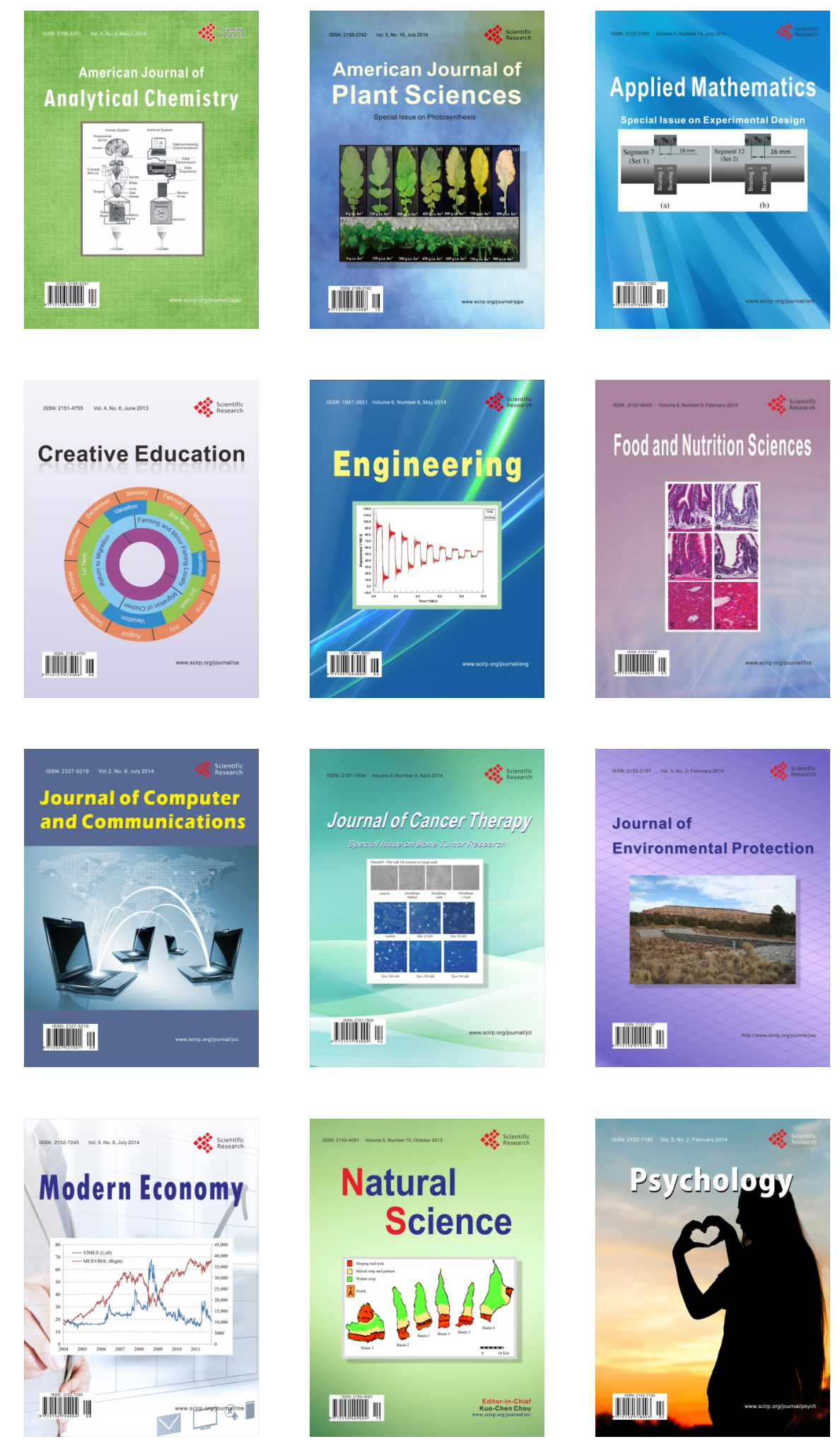